\title{
THE LAW, THE MOB, AND DESEGREGATION
}

On May 17, 1954, the Supreme Court of the United States in Brown v. Board of Education ${ }^{1}$ held that racially segregated education was inherently unequal and consequently a deprivation of constitutional rights under the fourteenth amendment. This case is destined to rank with those decisions of the Supreme Court that have radically changed the course of American history. Certainly no decision since that in the Dred Scott case has occasioned so inuch opposition. The Court, realizing that integration of the schools in areas where segregation had become the adopted mode of life would present many difficulties, held further hearings in order to formulate a plan for implementing its decision. On May 31, 1955, the Court decided that the details of desegregation enforcement were to be administered by the federal district courts in accordance with general equitable principles. ${ }^{2}$ Most of the recent cases for school desegregation have been equitable actions in federal courts. This comment will investigate the following problems which face those courts: (1) Should they refuse equitable relief in desegregation cases on the basis of the general maxim that equitable relief is not available when a decree requires prolonged or difficult supervision? (2) If equitable relief is granted, how can it be effectively enforced?

\section{DIFFICULTY OF SUPERVISION AS A BAR TO EQUITABLE RELIEF}

In order to prevent one case from occupying an undue amount of a court's time and to avoid ineffective judgments, courts have developed the maxim that equitable relief will not be granted in cases where a decree requires difficult or prolonged supervision. ${ }^{3}$ This maxim has most often been applied to building contracts ${ }^{4}$ or to long-term commercial agreements. ${ }^{5}$ In a few instances when enforce ment was considered extremely difficult the maxim was invoked to deny a plain tiff's request for enforcement of constitutional rights. ${ }^{8}$ Current events have indicated that desegregation orders often present complex and extended problems of enforcement. Should equitable relief in such cases therefore be refused?

In order to answer that question it is necessary to investigate the past application of the "difficulty of supervision" maxim in cases involving commercial contracts and in cases concerning constitutional rights.

\section{A. Commercial Cases}

A review of case law demonstrates that in a large number of the commercial cases where equitable relief was refused on the grounds of difficult or prolonged

1 Brown v. Board of Educ. of Topeka, 347 U.S. 483 (1954).

2 Brown v. Board of Educ. of Topeka, 349 U.S. 294 (1955). The scope of this comment is limited to actions in equity and does not include aclions at law for damages or federal criminal prosecution. For a discussion dealing with those aspects of the problem see articles cited in note 24 infra.

3 Javierre v. Central Altagracia, 217 U.S. 502 (1910); Giles v. Harris, 189 U.S. 475 (1903); Texas \& Pac. Ry. v. Marshall, 136 U.S. 393 (1890); Marble Co. v. Ripley, 77 U.S. (10 Wall.) 339 (1870) ; Kennard v. Cory Bros. \& Co., [1922] 2 Ch. 1.

4 Polerox, Equity JURISDICTION \$ 1402 (5th ed. 1941).

5 Javierre v. Central Altagracia, 217 U.S. 502 (1910); Marble Co. v. Ripley, 77 U.S. (10 Wall.) 339 (1870).

${ }^{6}$ Giles v. Harris, 189 U.S. 475 (1903); Kenyon v, City of Chicopee, 320 Mass. 528, 70 N.E.2d 241 (1946) (dictum). 
supervision, there also were other grounds given for refusing equitable relief. ${ }^{\top}$ Usually, when the plaintiff's remedy at law has been clearly inadequate and the threatened damage to him has been great, the courts lhave granted equitable relief despite the difficulty of supervision. ${ }^{8}$ The present position of the courts was best expressed in Zygmunt v. Avenue Realty $\mathrm{Co}^{9}{ }^{9}$ There the plaintiff requested specific performance of a contract requiring the vendor of land to build a street in front of a lot bought by the plaintiff. Granting specific performance, the court discussed both the inadequacy of the remedy at law and the importance of the relief to the plaintiff. The following statement by Professor Williston was quoted with approval: "Where the inadequacy of the damages is great and the difficulties (of enforcing the decree) not extreme, specific performance will be granted and the tendency in modern times has been increasingly towards granting relief."10

The court further stated that in an action for specific performance the difficulty of supervision is weighed against the importance of equitable relief to the plaintiff, and if the importance of such relief outweighs the difficulty of supervision, specific performance will be granted. The extent of the damages threatened to the plaintiff is therefore an important factor in determining whether specific perfornance will be granted in contracts requirmg difficult or prolonged supervision. However, of even greater significance is the question of whether the contract involves the public interest. When the enforcement of a contract has been considered to be in the public interest, specific performance has been decreed even when supervision was extremely difficult. For example, the Supreme Court of the United States has granted specific performance of contracts requiring perpetual supervision over railroad companies' agreements involving the use of eacli others' tracks. In these cases the Court stated that the importance of the contract to the public far outweighed any difficulty of supervision that might be encountered. ${ }^{11}$

7 E.g., in the three Supreme Court cases cited in note 3 supra, the Court based its refusal of equitable relief both on the ground of difficulty of supervision and on the ground that the plaintiff's remedy at law was adequate. In Javierre v. Central Altagracia, 217 U.S. 502 (1910), the plaintiff sued to enforce a contract for the purchase of all sugar cane grown by the defendant for a period of several years. The plaintiff requested an injunction to enjoin the sale of the sugar cane in any manner other than in accordance with the contract between the parties. The Supreme Court reversed the decision of a lower court in favor of the plaintiff on the grounds that the remedy at law was adequate and that the court, smce it will not undertake to supervise the growing and disposition of crops, ought not to try to accomplish this in a negative manner. In Texas \& Pac. Ry. v. Marshall, 136 U.S. 393 (1890), a city sued to enforce a contract with the railroad whicl provided that Marshall City would be the eastern terminus of the railroad. The Court felt that such a contract was against the public interest, that the city had an adequate remedy at law, and that the contract would be too difficult to enforce. Marble Co. v. Ripley, 77 U.S. (10 Wall.) 339 (1870), was a suit to obtain specific performance of a contract which obligated the defendant to deliver certain types and amounts of marble for as long as the plaintiff might desire. The Court refused specific performance on three grounds: (1) the judgment would require continuous supervision, (2) the contract lacked mutuality, and (3) the plaintiff had an adequate remedy at law, either by an action on the contract or under the provision of the contract which allowed the plaintiff to re-enter the quarry if defendant did not deliver the marble as agreed.

8 Union Pac. Ry. v. Chicago, R.I. \& Pac. Ry., 163 U.S. 564 (1896) ; Joy v. St. Louis, 138 U.S. 1 (1891); Brummel v. Clifton Realty Co., 146 Md. 56, 125 Atl. 905 (1924); Zygmunt v. Avenue Realty Co., 108 N.J. Eq. 462, 155 Atl. 544 (1931); Lane v. Newdigate, 10 Ves. 192, 32 Eng. Rep. 631 (Ch. 1804).

9108 N.J. Eq. 462,155 Atl. 544 (1931).

10 Id. at 465,155 Atl. at 545, quoting WuItston, Contracts $\$ 1423$ (1st ed. 1920).

11 Union Pac. Ry. v. Chicago, R.I. \& Pac. Ry., 163 U.S. 564 (1896); Joy v. St. Louis, 138 U.S. 1 (1891). In Standard Fashion Co. v. Siegel-Cooper Co., 157 N.Y. 60, 67, 51 N.E. 408, 409 (1898), the court expressed this policy as follows: "When the inconvenience of the courts in acting is more than counterbalanced by the inconvenience of the public if they do not act, the interest of the public will prevail." 
These decisions have sharply modified the general principle that equity will not grant rehef in cases involving long or difficult supervision of commercial contracts. Today a court of equity will demand that private inclividuals and corporations carry out their promises whenever breach would greatly harm the plaintiff or the general public. Do these same principles apply to situations involving constitutional rights?

\section{B. Cases Involving Constitutional Rights}

Cases concerning protection of constitutional rights present problems of enforcement often far more difficult than those raised by commercial cases. Under these circumstances the courts, at times, have despaired of doing justice and have refused to issue a decree that they felt would not be enforceable. In Giles v. Harris ${ }^{12}$ the Supreme Court denied equitable relief to Negro plaintiffs who had brought suit to compel the insertion of their names upon the voting hists of Montgoinery, Alabama. Justice Holmes, speaking for the Court, stated:

The bill imports that the great mass of the white population intends to keep the blacks from voting. To meet such an intent something more than ordering the plaintiff's name to be inscribed upon the lists of 1902 will be needed. If the conspiracy and the intent exist, a name on a piece of paper will not defeat thein. Unless we are prepared to supervise the voting in that State by officers of the court, it seems to us that all that plaintiff could get from equity would be an empty form. Apart from damages to the individual, relief from a great political wrong, if done, as alleged, by the people of a State and the State itself, must be given by them or by the legislative and political department of the government of the Umited States.13

The Giles decision has never been expressly overruled. However, it has been weakened considerably by a series of cases culminating in Terry v. Adams. ${ }^{14}$

In Terry, the white citizens of Ford Bend County, Texas, established an organization called the Jaybird Democratic Club. This club held advisory prinary elections from which all Negroes were excluded. The vinner of the advisory primaries always won in the official state primaries. The Supreme Court held that this practice constituted a deprivation of the Negro citizen's voting rights, and, in seeming disregard of the doctrine of Giles $v$. Harris, instructed the federal district court to hold such hearings and issue such orders and decrees ass would prove necessary to protect the Negro citizens. ${ }^{15}$

Injunctions have also been issued in labor disputes where the problem of enforcement has been extremely difficult. The courts issued these injunctions because they felt that the public interest demanded it. In In re Debs, ${ }^{10}$ the federal

12189 U.S. 475 (1903).

13 Id. at 488.

14345 U.S. 461 (1953). Other federal cases granting equitable relief were: Baskin v. Brown, 174 F.2d 391 (4th Cir. 1949); Rice v. Elmore, 165 F.2d 387 (4th Cir. 1947), cert. denied, 333 U.S. 875 (1948). Prior cases afforded relief at law for being deprived of the right to vote in primaries. Smith v. Allwright, 321 U.S. 649 (1944) ( $\$ 5,000$ damage suit).

15345 U.S. 461,470 (1953). When the case was first before the federal district court, the district court found in favor of the negro plaintiffs. However, equitable relief was refused because only four of the twenty-two directors of the Jaybird Club were parties to the action, and these four alone did not have the authority to change the club rules. The Supreme Court decision gave the plaintiffs the opportunity to join the other directors as defendants and instructed the court to grant equitable relief once the other directors were unade parties to the action.

16158 U.S. 564 (1895). The Debs case arose when the American Railway Union, in order to aid a strike against the Pullman Co., forbade its members to operate any trains which included Pullman cars. This action paralyzed the entire national railway system. The United 
courts enjomed umion officials from interfering with interstate transportation. Several thousand United States Marshals and federal troops were required to enforce this court order.

\section{Desegregation Cases}

It is clear from these cases that the maxim that equity will not grant relief in cases requiring difficult or prolonged supervision has been greatly modified. Today, equitable relief is available in all types of cases where the plaintiff can prove that there is an inadequate remedy at law and that the case is of great importance either to himself or to the general public. ${ }^{17} \mathrm{Can}$ a Negro plaintiff in school desegregation cases meet these requirements? Certainly a Negro student's remedy at law is inadequate $^{18}$ and the potential damage to him is very great. The importance to the plaintiff of obtaining equal educational opportunity was recognized by the Court in Brown I:

Today education is perhaps the most important function of state and local governments .... It is the very foundation of good citizenship .... In these days, it is doubtful that any child may reasonably be expected to succeed in life if he is denied the opportunity of an education ....19

Public interest in the education of American youth is equally clear. Therefore, reason would compel the conclusion that equitable relief should be available in sclool desegregation actions. Fortunately the cases lend authority to such conclusion.

In Brown II, the Supreme Court stated that the principle of desegregation may not be surrendered simply because of disagreement thereon. ${ }^{20}$ The United States Court of Appeals for the Sixth Circuit has held that a court may not exercise its equitable discretion to allow the continuance of deprivation of basic human rights. ${ }^{21}$ And in Aaron v. Cooper, ${ }^{22}$ the Court of Appeals for the Eighth Circuit stated that the vindication of rights guaranteed by the Constitution can not be conditioned on practical difficulties. The position of the federal courts was perhaps best expressed in the following statement of Judge Wright:

The problem of changing a people's mores, particularly those with an emotional overlay, is not to be taken lightly. It is a problem which will require the utmost patience, understanding, generosity, and forbearance from all of us, of whatever race. But the magnitude of the problem may not nullify the principle. And that principle is that we are, all of us, freeborn Americans, with a right to make our way unfettered by sanctions imposed by man because of the work of God.23

States Attorney obtained an injunction restraining Debs and others from interfering with the railroad companies. The leaders of the union nevertheless continued the strike. They were then arrested and convicted of contempt. See FrankFurter \& Greene, The Labor InJunction 17 (1930).

17 WaISE, A Treatise on Equity § 65 (1930); Simpson, Fifty Years of American Equity, 50 HARv. L. REv. 171, 173 (1936); 5 TEXas L. REv. 203, 206 (1927).

18 Damages in such a case would be lighly speculative. In order to recover damages the jury must have factual data-something more than guesswork-to guide them in fixing the award. McCoranck, DaMrages § 26 (1938).

10347 U.S. at 493.

20349 U.S. at 300.

21 Clemons v. Board of Educ., 228 F.2d 853, 857 (6th Cir. 1956).

22 257 F.2d 33 (8th Cir. 1958), aff'd, 358 U.S. 1 (1958).

23 Bush v. Orleans Parislı School Bd., 138 F. Supp. 336, 342 (E.D. La. 1956), aff'd, 242

F.2d 156 (5th Cir. 1957), cert. denied, 354 U.S. 921 (1957). 


\section{ENFORCEMENT OF DESEGREGATION DECREES}

Upon deciding that equitable relief is appropriate a court must consider the form of the judgment and the means of enforcing it. Considering the magnitude of the opposition to school desegregation, the effectiveness of any desegregation decree will depend to a large extent on the skill with which it is drafted and on the coercive power available to enforce it. The following sections of this comment will analyze the available forms a desegregation decree may utilize and the effectiveness of the contempt power of equity courts in enforcing such decrees. ${ }^{24}$

The Supreme Court's decision in Broven I was far ahead of the mores of the people which it primarily affected. Changes which run with the mores of the people are readily brought about, but those changes which run contrary to such mores require long and patient effort if they are possible at all. In many areas of our country community opposition to desegregation is very intense. The courts face very difficult problems where they attempt to enforce a law which is in direct conflict with the traditions and beliefs of a large and powerful part of the community. Community opposition to desegregation is expressed by one, or a combination, of three groups: the state government, the school officials and the general populace. ${ }^{23}$ A court faces vastly different problems depending upon which group or what combination of such groups oppose the desegregation order. In many areas the court can expect to encounter extensive evasionary tactics from state officials and school board members. These evasionary tactics will often be very difficult to deal with; however, it is possible for Negro plaintiffs to sue, ${ }^{26}$ and for federal courts to obtain jurisdiction over, state or school officials. ${ }^{27}$ On the other hand, opposition to de-

24 As an alternative to equity decrees criminal prosecution or actions for damages under the Civil Rights Acts may be employed to force desegregation. These remedies are beyond the scope of this comment. The applicable sections of the Civil Riglits Acts are 18 U.S.C. \$§ 241, 242 (1948), and 42 U.S.C. $\$ \S 1983,1985$ (1957). The use of these sections in enforcing school desegregation is discussed in Comment, 71 Harv. L. REv. 486, 500 (1958) ; Comment, 9 HasTINGS L.J. 167 (1958); Comment, 65 YALE L.J. 630, 648 (1956). It is important to realize that a jury trial is necessary in either criminal prosecution or damage actions under the Civil Rights Acts. This requirement sharply curtails the effectiveness of such actions in areas where desegregation is opposed by a large part of the population.

25 Community opposition to desegregation lias been expressed in the following combinations: (1) A portion of the populace alone expresses its opposition, while the state government and school board assert their reluctant willingness to comply (Tenn., Ky.). See Kasper v. Brittain, 245 F.2d 92 (6th Cir. 1957); Ops. Kx. ATr'Y GeN., 1 RACE Rez. Rep. 983, 1155 (1956). (2) A portion of the populace and the school board actually oppose the court order but the state government is willing to use its power to uphold the law (Ohio). See Clemons v. Board of Educ., 228 F.2d 853 (6th Cir. 1956). (3) A portion of the populace and the state government oppose the court while the school board is willing to comply (Ark.). Sce Faubus v. United States, 254 F.2d 797 (8th Cir. 1958), cert. denied, 358 U.S. 829 (1958); Aaron v. Cooper, 243 F.2d 361 (8th Cir. 1957). (4) A large portion of the populace are joined by the state government and the school board in determined and active ("massive") resistance to the court order. (Ala., Fla., Ga., La., Miss., N.C., S.C., Va.).

${ }^{26}$ All the school desegregation cases to date have been instituted by private individuals. Whether the United States Government could bring such a suit is unclear. Cf. In re Debs, 158 U.S. 564 (1895). See note 37 infra, for a listing of statutes under which a Negro student may sue state or school officials.

27 The major obstacle to federal jurisdiction over school or state officials is the eleventh amendment's prohibition of commencenent of any suit in a federal court against any of the United States by any citizen of another state or of a foreign state. This amendment applies also to a suit brouglit against a state by one of its own citizens. Hans v. Louisiana, 134 U.S. 1 (1889). A state can, of course, give its consent to be sued in a federal court. Gunther v. Atlantic Coast Line R.R., 200 U.S. 273, 292 (I906) ; Clark v. Barnard, 108 U.S. 436 (1883). However, some 
segregation on the part of private individuals who form into mobs to prevent effectuation of desegregation decrees presents difficult problems of federal jurisdiction as well as the problem of the court's ability to control nob action.

\section{A. Remedies Against School Officials}

Desegregation decrees are usually formulated as a result of class suits by Negro students against the school board members or other school officials. The desegregation order may take any of several forms. Many courts have ordered a school board to submit a plan outlining the course of action that the board intends to take to accomplish desegregation. ${ }^{28}$ When this plan is adopted by the court it becomes an official court order. Other courts merely have issued a general decree ordering a cessation of segregation. ${ }^{29}$ Under extraordinary circumstances the court has the power to issue its own plan, ${ }^{30}$ or to assign specific Negro plaintiffs to specific schools. $^{\text {.1 }}$

states have not only refused such consent but have passed statutes which specifically withhold state consent to suit in school desegregation cases. Acts of Assembly, Va. Ex. 1956 Chs. 68 (13), 1 RACE REL. REP. 1103 (1956). These statutes add nothing to the protection given by the eleventh amendment, and it has been held that a suit against a state official seeking to enjoin him from aiding segregation in the schools falls within the general proposition that a suit against a state official restraining him from unconstitutional conduct is not a suit against the state as defined in the eleventh amendinent. Georgia R.R. \& Banking Co. v. Redwine, 342 U.S. 299 (1952); Sterling v. Constatine, 287 U.S. 378 (1932); Ex parte Young, 209 U.S. 123 (1908); Orleans Parish School Bd. v. Bush, 242 F.2d 156 (5th Cir. 1957), cert. denied, 354 U.S. 921 (1957); School Bd. of Charlottesville, Va. v. Allen, 240 F.2d 59 (4th Cir. 1957), cert. denied, 353 U.S. 910 (1957).

Although federal jurisdiction is not open to doubt, nevertheless the federal courts have often refused to exercise jurisdiction and have required that a suit first be brought in the state courts. Federal courts may refuse to exercise jurisdiction if any of the following three conditions prevail: (1) if it is possible to decide the case on other than constitutional grounds; (2) if the case involves a question of state law upon which state courts have not yet ruled; or (3) if the court considers the case to deal largely with state domestic policy. Railroad Comm'n of Texas v. Pullinan Co., 312 U.S. 496 (1941). This doctrine is most often apphed to cases dealing with interpretations of state business regulatory statutes. But the courts bave on some occasions applied this policy to civil rights cases. Williams v. Dalton, 231 F.2d 646 (6th Cir. 1956). However, more often the doctrine has been considered inapplicable or the federal courts merely have stayed consideration of the case until state courts have acted. Lassiter v. Taylor, 152 F. Supp. 295 (E.D.N.C. 1957); Stapelton v. Mitchell, 60 F. Supp. 51, 55 (D. Kan. 1945), appeal dismissed sub nom. McElroy v. Mitchell, 326 U.S. 690 (1945). In the field of school integration it has been held that the federal courts will take jurisdiction because the Supreme Court in Brown $I I$ expressly instructed the federal district courts to supervise the desegregation of pubhic schools. Romera v. Weakly, 226 F.2d 399 (9th Cir.1955). See The Doctrine of Equitable Abstention, 2 RACE REL. REP. 1222 (1957).

23 Evans v. State Bd. of Educ., 149 F. Supp. 376 (D. Del. 1957); Mathews v. Launius, 134 F. Supp. 684 (W.D. Ark. 1955). Sometimes school board desegregation plans are adopted by a federal court without a previous court decree ordering the formulation of a plan. In Little Rock the school board voluntarily formulated a desegregation plan. Negro citizens sued the school board in order to obtain a revision of the plan so as to provide for faster desegregation. The Eighth Circuit held that the school board's plan was in accordance with the Brozen decisions and instructed the federal district court to retain jurisdiction and assure continued good faith desegregation by the school board. Aaron v. Cooper, 243 F.2d 361 (8th Cir. 1957).

29 Borders v. Rippy, 247 F.2d 268 (5th Cir. 1957).

30 Shedd v. Board of Educ. of Logan County, 1 RACE ReL. ReP. 521 (S.D. W.V. 1956).

31 The assignment of specific negro students to segregated schools was one of the methods employed to bring desegregation to Virginia. In August of 1958, Judge Paul, in School Bd. of Charlottesville, Va. v. Allen, remarked from the bench that if the school board does not show good faith the court would ". . . have to sit in and make the assignments of pupils." Charlottesville Daily Progress, Aug. 11, 1958, p. 1, col. 8. On September 13, 1958, Judge Paul ordered that 
The best approach would appear to be the utilization of an order compelling the school officials to submit a desegregation plan to the court. The Supreme Court in Brown II recognized the inherent difficulties of desegregation and encouraged local solutions to these problems. The Court in remanding the Brozen cases stated that the function of the federal district courts would be to determine whether the school officials were acting in good faith, while the primary responsibility for elucidating, assessing and solving the problems connected with desegregation should be left to local school authorities..$^{32}$ This may best be accomplished by letting the school officials formulate a plan and then adopting the plan as the court's order.

The civil contempt power of the court can in some instances be employed to force the school board to submit a desegregation plan and to enforce such plan.,33 In many circumstances school officials faced with punishment by civil or criminal contempt action will submit a desegregation plan that is satisfactory to the court and will abide by the terms of such scheme. If the plan submitted is not satisfactory to the court, the court may reject it and demand another, indicating in more detail what is required..$^{34}$ If the school board refuses to draft an acceptable plan,

twelve named Negro plaintiffs be enrolled in various formerly "white schools." On September 19, 1958, the Governor of Virginia closed these schools. 3 RACE REL. REp. 937 (1958). Other court decrees assigning specific negro plaintiffs to "white schools" were issued in Thompson v. County School Bd. of Arlington County, 166 F. Supp. 529 (1958), and Kilby v. County School Bd. of Warren County, Va., 3 RACE REL. REP. 9/2 (1958). Although all these schools were closed by the Governor of Virginia, desegregation was accomplished several months later when a federal court held that partial closing of the schools was unconstitutional. See text at note 71 infra.

32349 U.S. at 300.

33 There are two types of contempt proceedings, civil and criminal. Civil contempt proceedings are remedial rather than punitive. Gompers v. Bucks Stove \& Range Co., 221 U.S. 418, 441 (1911). The judgment may order the payment of a fine to the complainant to compensate him for his damages (McComb v. Jacksonville Paper Co., 336 U.S. 187 (1949)) or it may order imprisonment until such time as the defendants comply. Gompers v. Bucks Stove \& Range Co., supra; J.R. v. M.P., 37 Henry VI, 13, pl. 3 (C.P. 1459). Defendants in a civil contempt action have no rights to a jury trial. United States v. United Mime Workers, 330 U.S. 258 (1947); United States v. Onan, 190 F.2d 1 (8th Cir. 1951), cert. denied, 342 U.S. 869 (1951). No element of mens rea such as wilfulness or gross negligence need be proven. $M C C o m b v$. Jacksonville Paper Co., supra. The degree of proof necessary for conviction of civil contempt is merely clear and convincing. Telling v. Bellows-Claude Ncon Co., 77 F.2d 584 (6th Cir. 1935), cert. denied, 296 U.S. 594 (1935).

Criminal contempt proceedings are punitive in nature. They provide a deterrent to the wilful violation of desegregation decrees. The degree of proof required for conviction is beyond a reasonable doubt and the mens rea of wilfulness must be shown. Gompers v. Bucks Slove \& Range Co., sttpra. A jury is required only when the conduct which violated the court order is also a crime. 18 U.S.C. $\$ 3691$. (1952). No jury is required if the United States is a party to the action. For complete discussion of a jury trial in criminal contempt, sec Green v. United States, 356 U.S. 165 (1958). Criminal contempt proceedings may be initiated by the United States Government or the court. FED. R. CRns. P. 42(b). The court may if it wishes appoint the plaintiff's attorney as prosecutor on behalf of the court. McCann v. New York Stock Exchange, 80 F.2d 211 (2d Cir. 1935).

34 An excellent example of detailed instructions given to a school board in a desegregation case is Judge Hoffman's instructions to the Norfolk school bonrd given on August 25, 1958. When the Norfolk school board rejected all of 151 applications made by negro students for transfers to schools presently serving only white students, Judge Hoffman clearly and in great detail stated which grounds would be legally sufficient for denying the applications and which grounds were insufficient for denying such applications. The court held that possible feclings of isolation on the part of negro students or administrative problems due to racial conflicts were inadequate reasons for denying the requests for transfer. See: 3 RACE REx. REP. 946 (1958). The case was affirmed on appeal. School Bd. of City of Norfolk v. Beckett, 260 F.2d 18 
the court may, through the use of its contempt power, levy a high conditional fine on the members or imprison them until they comply. ${ }^{35}$ If the school officials resign pursuant to a conspiracy to prevent obedience to the court order, they may be guilty of criminal contempt. ${ }^{36}$ If stringent criminal contempt sanctions are applied, many school officials may be deterred from attempting to evade the court order through evasionary schemes. In addition, as long as the school system exists someone must be authorized to accept students. This individual or individuals can be ordered to accept specific Negro applicants im white schools. However, if the school officials, supported by the whole community, are very hostile to the court it may be impractical to attempt to force them to submit to a satisfactory plan. Such an attempt would occupy a great deal of the court's time and would most probably result in a plan drafted substantially by the court. When school officials continuously attempt to evade the court order it may be advisable for the court to formulate its own plan or to assign specific Negro students to white schools. As noted above such action would be imdesirable in that it would force the court to administer a school system. Furthermore, the assignment of specific students to specific schools is an inadequate technique in that it requires innumerable lawsuits to obtain even a very small degree of desegregation. However, im some situations this may be the best that can be obtained.

\section{B. Remedies Against Private Individuals}

After a school board has submitted a desegregation plan, or after some Negro students have been assigned to white schools, the major portion of the problem of enforcing the decree still remains. Events have illustrated that private individuals will on occasion, through the use of mob action, attempt to prevent the effectuation of court desegregation orders. As demonstrated in Kentucky and Tennessee, mobs are rather easily dealt with when the state is willing to exercise its police powers to keep order. But, where the community condones mob action against desegregation and the state refuses to curb mob action except on the condition that desegregation be abandoned, the court is faced with extremely difficult problems.

(4th Cir. 1958). Three days after the school board was instructed to reconsider all the applications seventeen of the negro students were accepted. School Bd. of City of Norfolk v. Beckett, supra. It is doubtful that a school board could escape punishment by claiming it did not understand a court decree unless it went back to the court for further instructions. A defendant who has an opportunity to move for elucidation of a decree and fails to do so is estopped from using the defense of vagueness. McComb v. Jacksonville Power Co., 336 U.S. 187 (1949); Lamb v. Cramer, 285 U.S. 217, 220 (1932).

35 See note 33 supra.

30 The general rule seems to be that inability to comply with a court order is a defense to criminal contempt only if the inability was not caused by the fault of the defendant. United States v. Moore, 294 Fed. 852 (C.C.N.Y. 1923), cert. denied, 264 U.S. 581 (1923); United States v. Bryan, 339 U.S. 323 (1950) (dicturn). In United States v. Green, 53 Fed. 769 (C.C.W.D. Mo. 1892) and United States ex rel. Watts v. Justice of Lauderdale County, 10 Fed. 460 (C.C.W.D. Tenn. 1882), officials who resigned in order to evade compliance with a court order were found in contempt of court simce, according to local law, the resignations were not effective until a successor had taken office. However, in United States ex rel. Watts v. Justice of Lauderdale County, supra, the court, by dicta, indicated that the act of resignation in order to evade the court order was not contempt of court. In People v. Pearson, 4 Ill. 270 (1841), a judge who failed to obey a writ of mandate was found in contempt after resignation since he could have pbeyed before he resigned and his act of contempt was complete before he resigned. Regardless of whether the resignation by school officials in order to evade desegregation orders is punishable by criminal contempt this tactic may often not be resorted to, since the abolition or suspension of the school board's activities is very disruptive to the whole school system. 
Court activities are greatly hampered where no effective local law enforcement agency cooperates with the court. One very formidable problem is the difficulty of acquiring federal court jurisdiction over the members of the mob. In the field of civil rights the jurisdiction of the federal courts is limited to assuring that the states afford equal protection of the law; it has no power to prevent private discrimination. ${ }^{37}$ However, in Hoxie v. Brewer, ${ }^{38}$ where desegregation was voluntarily undertaken by the school board, and in Kasper v. Brittain, ${ }^{30}$ where desegregation was compelled by court order, it was held that private action may be restrained by a federal court when such conduct interferes with the constitutional duties of a state or city official. The request for the injunction in both these cases came from the school officials. In many areas school boards will not apply for such injunctions. However, some language in Kasper seems to indicate that the Negro students may request, or the court may on its own initiative issue, a restraining order against private individuals who attempt to obstruct a federal court decree.

In Hoxie the school board requested an injunction against certain private individuals who were attempting to obstruct desegregation. The mob was threatening violence against both the school board members and the Negro students. In answer to protestations that the federal courts have no jurisdiction to enjoin private individuals, the court held that its jurisdiction arose from protection of the scliool board members. The court said the school board was sworn to uphold the constitution and therefore had a federally protected right to be free from illegal interference.

This reasoning has been criticized on the ground that since all state officials take oaths of allegiance to the Constitution, federal control would be indefinitely extended. ${ }^{40}$ The exact limits of the jurisdiction claimed in the Hoxie case have not been established. However, the extension of federal jurisdiction may not be too great if the principle is limited to situations in which private individuals wilfully and violently attempt to coerce state officials to use the power of the state in order to deprive other citizens of rights guaranteed them under the Constitution.

37 A suit to enjoin discrimination under color of state law may be brought directly on the basis of the fourteenth amendment or under the authority of 42 U.S.C. $\S \S 1983,1985$ (1957). Bell v. Hood, 327 U.S. 678 (1946). But it appears that no action against private discrimination can be based either on the fourteenth amendment or on the Civil Rights Acts. The fourteenth amendment has been held to restrict only state action. Civil Rights Cases, 109 U.S. 3 (1883). The Supreme Court has indicated that any suit based directly on the fourteenth amendment must be directed against persons acting under color of state law. Bell v. Hood, stipra at 684 (dictum). The same restrictions apply to the action based on the Civil Rights Acts, 42 U.S.C. $\$ 1983$ is expressly limited to conduct under custom or color of state law. Section 1985(3) attempts to provide a remedy against any persons who conspire to deprive others of equal protection of the law or to hinder the constituted state authorities from securing to all persons the equal protection of the law. However, several federal appellate courts have beld that this section applies only to conspirators who are acting under the authority of the state or under color of state law. Williams v. Yellow Cab Co. of Pittsburgh, 200 F.2d 302 (3d Cir. 1952); Moffett v. Commerce Trust Co., 187 F.2d 242 (8th Cir. 1951), cert. denied, 342 U.S. 818 (1951). In addition, $\$ 1985$ may not apply at all to the fourteenth amendment rights. Section 1985 is the civil counterpart to 18 U.S.C. $\$ 241$, which provides criminal sanctions against any persong who conspire to deprive others of equal protection of the law. An evenly divided Supreme Court held that $\$ 241$ covers only conduct which interferes with rights arising from the substantive power of the federal government, not with riglits guaranteed by the Constitution against abridgment by the states. United States v. Williams, 341 U.S. 70 (1951). (Justice Black concurred with the judgment on other grounds.)

38137 F. Supp. 364 (E.D. Ark. 1956), aff d, 238 F.2d 91 (8th Cir. 1956).

39245 F.2d 92 (6th Cir.), cert. denied, 355 U.S. 834 (1957).

40 Note, 70 HaRv. L. REv. 1299 (1957). 
As an alternate ground for jurisdiction the court in Hoxie held that the school board members were in such a close relationship to the Negro children that they were empowered to sue on their own behalf."11 This second ground of jurisdiction assumes that the court had power to entertain a suit by the Negro children. This reasoning would be acceptable only if some state action were involved. The attempt to exert mob pressure on state officials may be sufficient state action to allow suit by the Negro students. Where, however, the private action is not aimed against the school board but only against the students, it would appear to be impossible to find state action. Therefore, in the absence of a court decree ordering desegregation, an injunction against private action can only be obtained if such action is aimed against public officials, and the request for the injunction must come from such public officials. As previously stated, school board requests for this type of restraining order may be very rare.

However, when private interference is aimed at desegregation which is being undertaken in comphiance with a court order, an additional ground of jurisdiction may exist. In Hoxie desegregation was voluntary, but in Kasper desegregation was undertaken in compliance with a federal court order. John Kasper, by inciting a mob, attempted to obstruct the court decree. The court, in granting the school board's request for a supplementary injunction against Kasper, based its jurisdiction primarily on the same grounds as in Hoxie. However, in response to Kasper's objection that the case was closed when the school board complied with the desegregation decree, the court stated that a federal court is always empowered to enforce its decree by orderly process. ${ }^{42}$ Where desegregation is pursuant to a court order, it may therefore be possible for the Negro plaintiffs to request a supplementary injunction against private individuals who attempt to obstruct the original court decree. It seems only reasonable that federal jurisdiction in such a case would exist under the ancillary power of equity courts. If this is the case, then demagogues who incite mob action against court orders can be enjoined from continuing such conduct. It must be pointed out that in the absence of requests by school officials for federal protection the jurisdiction of the federal courts over individual mob members rests solely on the ancillary power of equity courts. Hence it does not exist unless a court order exists. Furthermore, the law in this field is not well defined. Whether the federal courts will claim jurisdiction over private individuals on the basis of their ancillary power is problematical. If such jurisdiction is rejected, a powerful weapon against the mob will be lost. The school boards will rarely ask for federal help. If no supplementary injunction against inob leaders is obtainable at the request of the Negro plaintiffs, control of the mobs will be very difficult. Undoubtedly, one of the most effective means of quashing mob action is to act quickly and decisively against its leaders.

However, even if a school board applies for a supplementary injunction or if the Negro plaintiffs are permitted to request such injunction, the injunction will be of limited use. It will not prevent a private person from interfering with a court desegregation order until such person or someone with whom he is acting in concert $^{\mathbf{4}}$ is brought into court and ordered to refrain from such action. Such a procedure is useful only in restraining known mob leaders; it is not a general deterrent.

41137 F. Supp. at 367 .

42245 F.2d at 96.

43 In the Kasper case seventeen persons in addition to Kasper were tried for criminal contempt. Seven of them were convicted for acting in concert with Kasper. United States v. Kasper, 2 RACE REL. REP. 795 (1957). 
A general deterrent to interference with a court order may, however, exist in the contempt power of the court. Whether strangers to an action who misbehave outside the presence of the court can ever be punished by federal contempt proceedings is a matter of dispute. The federal law is determined by the common law as modified by two statutes, Section 401 of the Criminal Code ${ }^{44}$ and Section 19 of the Clayton Anti-Trust Act, ${ }^{45}$ now codified in Federal Rules of Civil Procedure 65 (d). ${ }^{46}$ Under the common law and undoubtedly under present federal law an mjunction binds only parties to the action and those acting in concert with such parties, and no one else can be punished for disobedience to the lawful writ, process, order, rule, decree, or command of the court. This was not only the common law of England but was reiterated and permanently adopted as the law of the United States by the passage of the Clayton Anti-'Trust Act. However, the common law of England and of the United States prior to the passage of the Clayton Act authorized a court to punish persons who interfere with the course of justice.47 Under this doctrine any person who did an act which he knew others were enjoined from domg could be punished not for violation of the injunction but for showing disrespect to the court. ${ }^{48}$ This led to the punishment of persons who had no opportunity to hitigate their rights. After a long struggle by labor, against whom this weapon was most often employed, the Clayton Act was adopted..$^{40}$ However, this act nerely provided that every injunction and restraining order is binding only upon the parties to the action or those acting in concert with them. No mention was made as to the jurisdiction of the federal courts to punish by contempt proceedings persons dehiberately obstructing justice. The decisions restricting the courts' power to punish for contempt ${ }^{50}$ have dealt with punishment for violation of an injunction, not for obstruction of justice. According to some cases, Section 19 of the Clayton Act did not change but was merely declaratory of the commion law. ${ }^{\text {g1 }}$ However, the purpose of the Clayton Act would seem to indicate that this section was intended to change the common law, and to deprive federal courts of the power to punish nonparties to an injunction who, with knowledge of the injunction but

4418 U.S.C. $\$ 401$ (1950) provides: "A court of the United States shall have power to punish by fine or imprisonment at its discretion, such contempt of its authority, and none other, as (1) Misbehavior of any person in its presence or so near thereto as to obstruct the administration of justice; (2) Misbehavior of any of its officers in their official transactions; (3) Disobedience or resistance to its lawful writ, process, order, rule, decree or command." Section 401(1) was himited by the Supreme Court to action so near the court geographically as to obstruct justice. Nye v. United States, 313 U.S. 33 (1941).

4538 Stat. 738 (1914).

${ }^{46} \mathrm{FED}$. R. Crv. P. 65(d) states that "every order granting an injunction and every restraining order ... is binding only upon the parties to the action, their officers, agents, servants, employees, and attorneys, and upon those persons in active concert or participation with them who shall receive actual notice of the order by personal service or otherwise."

47 United States v. Shipp, 203 U.S. 563 (1906); Seaward v. Patterson, [1897] 1 Ch. 545.

48 Seaward v. Patterson, [1897] 1 Ch. 545, 555.

40 Frankfurter \& Greene, The Labor InJunction 154 (1930).

60 Chase National Bank v. City of Norwalk, 291 U.S. 431 (1934); Kean v. Hurley, 179 F.2d 888 (8th Cir. 1950); Le Tourneau Co. of Ga. v. NI.RB, 150 F.2d 1012 (5th Cir. 1945), rev'd on other grounds, 324 U.S. 793 (1944); Internationai Brotherhood of Teamsters, Local 523 v. Keystone Freight Lines, 123 F.2d 326 (10th Cir. 1941); Aleınite Corp. v. Staff, 42 F.2d 832 (2d Cir. 1930) ; United States v. Wilhelm Reich Foundation, 17 F.R.D. 96 (S.D.Me. 1954), affd, 221 F.2d 957 (1st Cir. 1955), cert. denied, 350 U.S. 342 (1950).

51 NLRB v. Blackstone Mfg. Co., 123 F.2d 633, 635 (2d Cir. 1941). Cf. Regal Knitwear Co. v. NLRB, 324 U.S. 9 (1945). 
acting independently, commit the act enjoined. ${ }^{52}$ But it can be argued that the Clayton Act ought not to be extended to situations where the stranger atteinpts to coerce the defendant into violating the decree. It would seem reasonable that if a third party attempts to coerce or induce a defendant to disobey a court order, such third party is guilty of contempt. ${ }^{53}$ The same reasoning may be applied to acts coercing a planitiff in the suit from enforcing his rights under such decree. If one person is enjoined from picketing the plaintiff's plant and later a stranger to the case pickets the plant he ought not to be found in contempt of court. But, if the stranger, by coercion, attempts to prevent the plaintiff from enforcing the decree against the defendant or in other ways deliberately attempts to interfere with the enforcement of the original judgment he ought to be guilty of contempt under Section 401(3) of the Criminal Code; not for disobedience of the injunction but for resistance to the court order. ${ }^{54}$ This, in effect, was held to be the law in Russel v. United States. ${ }^{55}$ Russel, who was taking photographs of a strike, attempted to prevent a federal marshal from removing soine machinery from a factory by breaking a inilk bottle in front of the marshal's truck. The marshal was noving the machinery in compliance with a replevin judgment. Russel was neither a party to the replevin action nor an employee of either party. He was not even directly connected with the strike. Nevertheless the court punished him in a criminal contempt proceeding for his deliberate interference with the court's judgment. The fact that a federal marshal was involved ought not to be considered significant. Although Section 1501 of the Criminal Code ${ }^{56}$ provides for criminal punishment of persons obstructing any officers of the United States, Russel was not prosecuted under this statute. He was prosecuted for contempt of court and the proceeding against him had to be under section 401(3). This section is apphicable to all contempt proceedings and makes no distinction between resistance which is aimed against a federal marshal or against some other persons. Hence it may well be that a court has the power to punish any individuals who attempt either to coerce school board officials from obeying the court decree or try to prevent Negro students from entering the schools. However, the law in this area has not been clearly defined by the United States Supreme Court. It may be that crininal contempt punishment is limited only to parties to the action and those acting in concert with such parties and is not applicable against persons who attempt to coerce the plaintiffs or defendants. If this is true, control of a mob by judicial process will be greatly hampered. Under such circumstances either local law enforcement (which may refuse to act) or federal troops (which can only restrain, not punish) must be rehed upon.

\section{Remedies Against State Officials}

It appears from the foregoing discussion that courts may often, by virtue of both their prestige and contempt power, be able to persuade school officials to formulate a desegregation plan. In any case, they may at least be able to order these officials to accept certam specific Negro students into "white schools." Further-

52 Frantrurter \& Greene, The Labor InJUNCtion 159 (1930).

53 Cf. Smith v. State, 36 Ga. App. 37, 135 S.E. 102 (1926).

54 United States v. Shipp, 203 U.S. 563 (1906); In re Lennon, 166 U.S. 548 (1897) ; NLRB v. Blackstone Mfg. Co., 123 F.2d 633 (2d Cir. 1941); Russel v. United States, 86 F.2d 389 (8th Cir. 1936); Kelton v. United States, 294 Fed. 491, (3d Cir. 1923) ; Raymor Co. v. Buck, 110 F.2d 207 (1st Cir. 1940) (quote of lower court dictum). Cf. Regal Knitwear Co. v. NLRB, 324 U.S. 9 (1945).

55 86 F.2d 389 (8th Cir. 1936).

5018 U.S.C. $\$ 1501$ (1948). 
more, the courts probably have a means of punishing private individuals who attempt to interfere violently with desegregation orders. Therefore, although it will be no easy task for the courts to enforce an order that is contrary to the general community sentiment, some means do exist to control opposition to desegregation orders originating from school officials or private individuals. The final source of opposition is the state government. Opposition from state governments may be based upon a specific statute adopted in order to delay desegregation or may be independent of such statute. These different forms of opposition will be discussed separately.

Where state officials attempt physically to prevent Negro students from entering white schools or in other ways interfere with the court order, supplementary mjunctions may be obtained by the Negro students to restram the obstructionist activities. ${ }^{57}$ Once such supplementary injunctious are obtained, both civil and criminal contempt can be employed to enforce them. In Little Rock, Arkansas the governor used the National Guard to prevent Negro children from entering a high school which was ordered by a federal court to desegregate. A supplementary injunction was obtained restraiming the governor and National Guard officers from further interference with the court order. ${ }^{58}$ Upon issuance of the injunction the National Guard was withdrawn.

Most state opposition has been taken pursuant to special state legislation. A full discussion of the constitutionality of state legislation adopted to delay desegregation is beyond the scope of this paper. However, due to the importance of this legislation in the problem of enforcing the court decree, a short survey of some of these laws and the thus far limited number of cases dealing with these laws will be undertaken.

The various state legislative attempts to prevent desegregation differ somewhat; lowever, most of these plans contain the following three devices: ${ }^{50}(1)$ an act requiring segregation, (2) a pupil placement law, (3) a law allowing the governor to close integrated schools.

\section{Acts requiring local officials to administer only segregated schools}

After Brown II many southern states adopted legislation stating that segregated education was necessary for the protection of public health and morals. The statutes purport to exercise the police power of the state and require local school officials to administer all schools on a segregated basis. ${ }^{60}$ These laws were quickly

57 See note 37 supra.

58 Aaron v. Cooper, 156 F. Supp. 220 (E.D. Ark. 195'), af'd sub nom. Faubus v. United States, 254 F.2d 797 (8th Cir. 1958), cert. denied, 358 U.S. 829 (1958). Judge Davies' order stated that the Governor of Arkansas and officers of the National Guard are enjoined from: "(a) obstructing or preventing, by means of Arkansas National Guard or otherwise, negro students to attend Central High School, from attending said school or, (b) from threatening or coercing said students not to attend said school or, (c) from obstructing or interfering in any way with the carrying out and effectuating of this court's order of August 28, 1956 and September 3,1957 , in this case or from otherwise obstructing or interfering with the Constitutional rights of said children to attend said school ..." Aaron v. Cooper, sucpra at 222. After the National Guard was withdrawn, mob action forced the President of the United States to use federal troops to enforce the original desegregation decree. Executive Order 10730, 22 Fed. Reg. 7628 (1957).

59 For a good example of such laws see, Acts of Assembly, Va., Ex. 1956 chs. 56-71, 1 RAcE REL. REP. 1091 (1956).

60 E.g., LA. REv. STAT. tit. $17 \S 331$ (Cum. Supp. 1957). The act provides as follows: "All public and elementary and secondary school education in the state of Louisiana shall be operated separately for white and colored children. This provision is made in the exercise of the state police power to promote and protect public health, morals, better education and the peace and good order in the state and not because of race." 
challenged and declared unconstitutional. 1 The use of the words "police power" or "health and public morals" provides no magic which transforms an unconstitutional law into a constitutional one. Statutes of this nature are in direct conflict with Brown $I$ and $I I$ and fall under the supremacy clause of the Constitution. ${ }^{62}$

\section{The pupil placement law}

Pupil placement laws have been adopted in ten states. ${ }^{63}$ These statutes deprive individual schools of the power to accept new or transferring students, and place such power solely in a statewide board, school superintendent or local board of education. The acts provide for very extensive state administrative and judicial review of the placement authorities' decision. The Virginia law requires that when a parent is dissatisfled with the assignment of his child the placement authority is to hold hearings at which any parent of a child attending the school concerned may offer testimony. If the complainant is still dissatisfied with his assignment he may appeal to the governor and is required to pay for and prepare a full transcript of the proceedings before the placement authority. ${ }^{64}$ The total time required for full administrative review under the Virginia statute is 105 days.

The objective of these laws is to force individual consideration of each Negro application and to prevent the issuance of federal desegregation orders by bogging down the Negro students in endless review proceedings. Where these laws exist, whenever Negro students sue in federal or state courts for admittance to a white school, the school boards have usually interposed the defense of failure to exhaust administrative remedies. ${ }^{65}$ This defense has been rejected in cases arising in Virginia and Louisiana on both the grounds that the pupil placement laws were unconstitutional on their face and that equity will not require a plaintiff to exhaust his administrative remedies if such remedy is inadequate. ${ }^{66}$

01 Orleans Parish School Bd. v. Bush, 242 F.2d 156 (5th Cir. 1957), cert. denied, 354 U.S. 921 (1957).

62 U.S. Consr. art. VI. The federal court will enjoin any state judgment based on this type of law. Thompson v. Cooper, 254 F.2d 808 (8th Cir. 1958).

63 Ala. Code AnN. tit. $52 \S 61$ (Cum. Supp. 1955); Ark. Stat. ANn. $\$ \S 80-1519$ to 1525 (Cum. Supp. 1957) ; Fla. Stat. AnN. §§ 230-231 (1957); La. Rev. Stat. tit. 17 \$ 81.1 (Cum. Supp. 1958); Miss. Code ANN. \$\$ 6334-01 to 08 (Cum. Supp. 1956) ; N.C. Gen. Stat. \$§ 115176 to 179 (Cum. Supp. 1957); S.C. CoDE $\$ \S 21-230,21-247$ to 247.7 (Cum. Supp. 1956); Tenn. Code Ann. \$§ 49-1701 to 1764 (Cum. Supp. 1958); Vernow's Texas Stat. art. $2901 a$ (Supp. 1958); VA. Code ANN. \$\$ 22-232.1 to 232.16 (Cum. Supp. 1958).

64 Acts of the General Assembly of Va. (1956, Ex. Sess., c. 70). The pupil placement law was amended in 1958. VA. CODE ANN. \$§ 22-232.1 to 232.16 (Cum. Supp. 1958).

65 Generally equity will refuse to take jurisdiction of a case where the complainant has not first exhausted his administrative remedies. Myers v. Bethlehem Shipbuilding Corp., 303 U.S. 41 (1938); Prentis v. Atlantic Coast Lime Co., 211 U.S. 210 (1908).

60 Orleans Parish School Bd. v. Busb, 138 F. Supp. 336 (E.D. La. 1956), aff'd, 242 F.2d 156 (5th Cir. 1957), cert. denied, 354 U.S. 921 (1957); Adkins v. School Bd. of City of Newport News, 148 F. Supp. 430 (E.D. Va. 1957), aff'd, 246 F.2d 325 (4th Cir. 1957), cert. denied, 355 U.S. 855 (1957). Exceptions to the rule requiring exhaustion of administrative remedies are made if it appears that the administrative agency is bound by policy or regulations of a bigber governmental authority to give a ruling adverse to the complainant, Waite v. Macy, 246 U.S. 606 (1918), or where the existence of the administrative remedy is for some other reason doubtful. Umion Pac. R.R. v. Board of County Comm., 247 U.S. 282 (1918). See also, Exhaustion of Adninistrative Remedies, 2 RACE REL. REP. 561 (1957); Berger, Exhaustion of Administrative Remedies, 48 Yade L.J. 981 (1939).

In Adkins, supra, the court held that in light of the policy and laws of the State of Virginia in opposition to desegregation the administrative remedies provided by the school placement laws were inadequate. The court further held that the law was a mere substerfuge aimed at 
However, in North and South Carolina the federal courts have refused to hold the pupil placement laws unconstitutional on their face. ${ }^{67}$ Decision as to whether these laws are unconstitutional in application was deferred until such time as the Negro students finished complying with the pupil placement law requirements. The administrative review required by the laws of both of these states was not so extensive as to preclude prompt recourse to the courts if the pupil placement authority discriminated upon the basis of race. Furthermore, state policy and law did not expressly prevent the placement board from assigning Negro children into white schools. Under the North Carolina act some Negro children have been assigned to white schools.

The school placement laws also provide for judicial review by state courts. However, plaintiffs need not exhaust state judicial review before suing in federal court. ${ }^{68}$ When state judicial review has not been exhausted, jurisdiction of the federal courts is discretionary; the federal courts have indicated that in school desegregation cases such jurisdiction would be exercised. ${ }^{60}$

It would appear therefore that a pupil placement law designed to nullify a Negro student's rights to desegregated education is void. Such law will not prevent the issuance of court decrees against local school officials. On the other hand, pupil placement board laws which do not require unreasonable administrative roadblocks will be upheld, but the pupil placement boards' action is subject to federal review, and if the law is administered so as to cleprive negroes of desegregated education such action will be overruled. The case of Thompson v. Cozinty School Board of Arlington County ${ }^{70}$ is an excellent example of detailed judicial review of a pupil placeinent board's actions. The court carefully examined the reasons given for the rejection of thirty Negro applications to transfer to "white schools". The court found that the Pupil Placement Board's decision in the case of four students was unjustified and ordered that they be admitted to the segregated schools.

\section{The closing of the schools}

As a last ditch effort to delay desegregation some states have adopted laws authorizing the governor to close public schools."1 This type of statute has two flaws. First, it leads up a blind alley in that the schools cannot rationally remain forever closed, ${ }^{72}$ and secondly, such acts are unconstitutional if applied only to

retaining school segregation and was consequently unconstitutional. Even after the 1958 amendments to the Virginia act, the federal courts still indicated that the administrative remedy was too cumbersone. Thompson v. County School Bd. of Arlington County, 166 F. Supp. 529 (E.D. Va. 1958). In Bush, supra, the court held that the school placement law was unconstitutional because the school superintendents were not provided with any standard upon which to base assignments except an implied standard of race.

67 Carson v. Warlick, 238 F.2d 724 (4th Cir. 1956), cert. denied, 353 U.S. 910 (1957); Hood v. Board of Trustees, 232 F.2d 626 (4th Cir. 1956).

68 Lane v. Wilson, 307 U.S. 268, 274 (1939); Carson v. Warlick, 238 F.2d 724, 728 (4th Cir. 1956), cert. denied, 353 U.S. 910 (1957).

60 Ibid. For factors influencing a federal court decision on whether it should exercise jurisdiction and the effects of state laws withholding a state's consent to suit in school desegregation cases, see note 27 supra.

70166 F. Supp. 529 (E.D. Va. 1958). Cf. Judge Hoffman': statement to Norfolk School Board, 3 RACE ReL. Rep. 946 (1958).

71 E.g., VA. Code ANN. \$§ 22-188.46 to 188.48 (Cum. Supp. 1958).

7217,000 students have at one time been locked out of school due to school closing laws. Many of these students received private education provided by "Emergency Parent Committees" in churches and basements of private bomes. Such education has many disadvantages. See, When Public Schools Close, What Happens to Students, U.S. News and World Report, Oct. 31, 1958, p. 48. See also James v. Almond, 27 U.S.L. WeEK 2361 (E.D. Va. Jan. 19, 1959). 
schools where intergration has been ordered. ${ }^{73}$ In order to overcome the first weakness Virginia devised a scheme to reopen the schools as "private imstitutions." However, money to operate the schools must still be provided by the state. This need has been net in Virginia by authorizmg state grants to students who attend secular "private schools" 74 and state pensions for teachers who teach in these schools. ${ }^{75}$ There is usually also some provision for leasing the school building. Under these circumstances state action is not even subtly disguised. There is very little difference indeed between these private schools and the private priniary elections in Terry $v$. Adams. ${ }^{76}$ The federal courts have had very hittle difficulty in applying the principles of Brown $I$ and $I I$ to this type of state supported "private school." The Supreme Court in Aaron v. Cooper" s7 said: "State support of segregated schools through any arrangement, management, funds, or property cannot be squared with the Amendment's command that no State shall deny to any person within its jurisdiction the equal protection of the laws." Following this mandate, federal courts in both Arkansas and Virginia have enjoined the use of public school buildings or state paid teachers by the so-called "private schools."78

The second flaw in the school closing laws is that they are unconstitutional if applied only to schools which have been ordered to integrate. A three judge federal court in James $v$. Almond ${ }^{79}$ held that the closing of only integrated grades or schools is a violation of equal protection of the law as far as the Negro students were concerned and a deprivation of due process as to all children who are willing to attend school with nembers of the opposite race. The court said:

While the State of Virginia directly or indirectly maintains and operates a school system with the use of public funds, or participates by arrangement or otherwise in the inanagement of such school system, no one public school or grade in Virginia may be closed to avoid the effect of the law of the land as interpreted by the Supreme Court, while the state permits other public schools or grades to remain open at the expense of the taxpayers. 80

The court in the James case pointed out that if the city or county took over the management of the schools from the state the same principles with respect to equal protection of the law would be applicable.

73 James v. Almond, 27 U.S.L. Weex 2361 (E.D. Va. Jan. 19, 1959) ; N.Y.Times, Jan. 20, 1959, p. 29.

74 VA. Const. art. IX, §141; VA. CoDE ANv. §§ 22-115.1 to 22-115.2 (Cum. Supp. 1958). The Virginia Supreme Court has ruled that the diversion of funds from schools to state grants for use by students attending nonsectarian private schools is contrary to art. IX, $\S 129$ of the Virginia Constitution. This section requires the state to maintain a free public school system. Harrison v. Day, 27 U.S.I. WeEk 2361 (Va., Jan. 19, 1959); N.Y. Times, Jan. 20, 1959, p. 28. It unust be noted that such constitutional protection is based on the state constitution and does not have nationwide application. Furthermore, the state constitution is subject to change by the voters of the state who are overwhelmingly opposed to desegregation. The Virginia Supreme Court expressly refused to base its decision on any provision of the United States Constitution.

75 VA. Code ANN. § 51.111.38:1 (Cum. Supp. 1958).

76 See text at note 14 supra.

77358 U.S. 1, 19 (1958).

78 Aaron v. Cooper, 261 F.2d 97 (8th Cir. 1958); Allen v. Charlottesville School Bd., 27 U.S.L. WEeK 2173 (W.D. Va. 1958). In Allen the court said: "If the state is going to abandon public education it must do so completely and not continue it under the guise of private schools supported by state funds. As long as the schools are operated with public support, they inust be operated on a desegregated basis."

79 27 U.S.L. WeeK 2361 (E.D. Va. Jan. 19, 1959) ; N.Y. Times, Jan. 20, 1959, p. 29.

80 Ibid. 
Following the James and Harrison v. Day ${ }^{81}$ cases the massive resistance program of Virginia collapsed massively. 82

Despite these defects in the school closing laws, school boards have often based their plea for more time on the existence of these laws. But it has been held that the threat of school closing will not deter the issuance of desegregation decrees. ${ }^{83}$ The court in Allen v. County Board of Prince Edward County ${ }^{84}$ said:

The fact that the schools might be closed if the orders were enforced is no reason for not enforcing it. A person may not be denied enforceinent of rights to which he is entitled under the Constitution of the United States because of action taken or threatened in defiance of such rights.

\section{CONCLUSION}

There remains little doubt that the opposition of the community as represented by actions on the part of school officials, mobs, and state officers presents an extremely complex problem of enforcement. However, the problem is in many cases not insurmountable. It would appear that school officials, either school board members, or, if these have resigned, such other officials as are responsible for admitting students, can be forced to accept certain specific Negro students. At best, they can be persuaded to submit to and follow a plan of desegregation. With the help of a large number of federal marshals and the deterrent effects of the criminal contempt power it may be possible to minimize mob opposition. Finally, some forms of state opposition are readily countered (direct interference, such as preventing access to the school) while other forms are extremely difficult to overcome (closing of all the schools). However, the cost of such state opposition as the closing of all public schools is very great to the general education of the children of that state, and will usually be abandoned after a period of time..$^{85}$ Nevertheless, it is apparent that in those states where the populace, school officials, and state government combine to oppose desegregation the most that can be lioped for is some assignments of a small number of Negro students to white schools. In many areas the residential pattern will cause most schools to continue to serve only or predominantly the members of one race. ${ }^{86}$ Furthermore, the antagonisin shown by white students to the newly entering Negro students ${ }^{87}$ and the econoumic pressures exerted by the community

8127 U.S.L. WEEK 2360 (Va. Jan. 19, 1959); N.Y. Times, Jan. 20, 1959, p. 28.

82 On Feb. 2, 1959, six schools in Norfolk, Va. were desegregated. N.Y. Times, Feb. 3, 1959 , p. 1.

83 Allen v. County School Bd. of Prince Edward County, 249 F.2d 462 (4th Cir. 1957), cert. denied, 355 U.S. 953 (1958); Adkins v. School Bd. of City of Newport News, 148 F. Supp. 430 (E.D. Va. 1957), aff'd, 246 F.2d 325 (4th Cir. 1957), cert. denied, 355 U.S. 855 (1957).

84249 F.2d 462, 465 (4th Cir. 1957), cert. denied, 355 U.S. 953 (1958).

85 In Virginia the Parent-Teachers Association recommended that local school districts be allowed to reopen the schools on an integrated basis if they so desire. N.Y. Times, Oct. 23, 1958, p.1. The following semester desegregation came to Virginia. Governor Almond stated to an emergency session of the Legislature that he was powerless to prevent integration of those schools facing inminent desegregation under federal court orders. He said: "No fair-minded person would be so unreasonable as to seek to hold me responsible for failure to exercise powers which the state is powerless to bestow." N.Y. Times, Feb. 1, 1959, § E, p.1.

86 Although children inay be assigned to schools on the basis of geographical location, gerrymandering of school districts in order to separate pupils by race is unconstitutional. Clemons v. Board of Educ. of Hillsboro, 228 F.2d 853 (6th Cir. 1956).

87 Discipline within the school was one of the major problems in Central High School at Little Rock, Arkansas. Aaron v. Cooper, 257 F.2d 33 (8tlı Cir. 1958), aff'd, 78 Sup. Ct. 1399 (1958); White pupils act to oust Negroes in Van Buren, Ark., N.Y.Tunes, Sept. 5, 1958, p. 16, col.3. 
on Negro parents ${ }^{88}$ will discourage many Negro children from attending schools now exclusively serving white students. In addition in some areas the more well to do portion of the white population may turn to bona fide private schools. It seems that true acceptance of the principles of integration, in education as well as in other phases of life, must be based upon the acceptance of the ideals underlying the fourteenth amendment and not upon court decrees. Nevertheless, the Brown decisions may very well bring at least token desegregation to every state in the Union. The decisions will bring substantial desegregation to those commumities ready to accept it but which have formerly been prevented from adopting it due to state law. In addition, Brown $I$ has provided the moral leadership which has brought widespread integration to Washington, D.C., some of the border states, and to those Northern communities that still had segregated facilities in 1955.89 Gary A. Schlessinger*

88 U.S. News \& World Report, Oct. 29, 1954, p. 29; U.S. News \& World Report, May 28, $1954, \mathrm{p} 21$.

80 As of August 24, 1958, W. Va. had adopted integreation in $100 \%$ of its bi-racial school districts, Md. $91 \%$, Mo. $86 \%$, Okla. $80 \%$, Ky. 67\%, Del. $30 \%$, Texas $17 \%$, Ark. $4 \%$, Tenn. $2 \%$, N.C. $2 \%$, and Ala., Ga., La., Miss., S.C., and Va., 0\%; N.Y.Times, Aug. 24, 1958, § E, p. 7, col. 2. On Feb. 2, 1959, six schools in Va. were desegregated. N.Y. Times, Feb. 3, 1959, p. 1.

* Member, Second-Year Class. 